О. О. Броварець, к.m.н., дочент

e-mail: brovaretsnau@ukr.net

Київський кооперативний інститут бізнесу і права вул. Ломоносова, 18, м. Київ, 03041, Україна

\title{
ВИКОРИСТАННЯ СУЧАСНИХ ІНФОРМАЦЙНО-ТЕХНІЧНИХ СИСТЕМ У АГРОПРОМИСЛОВОМУ ВИРОБНИЦТВІ
}

Стаття присвячена оптимізації урожайності і забезпеченню екологічної якості сільськогосподарської продукиії за допомогою сучасних інформачійно-технічних систем, із урахуванням варіабельності зон управління сільськогосподарським полем. Запропоновано неоднорідність трунту представити як ієрархічну підпорядкованість явищ. При цьому питання вимірювання неоднорідності пропонується вирішити иляхом кількісного порівняння об'єктів вимірювання з використанням відповідних критеріїв. За иих умов виникає необхідність у пошуку найбільш ефективного способу для оперативного моніторингу агробіологічного стану сільськогосподарських угідь, що відкриває нові перспективи до ведення органічного землеробства з використанням інтелектуальних сільськогосподарських машин.

Ключові слова: інформаційно-технічна система, оперативний моніторинг, трунт, проби, варіабельність, величина.

Постановка проблеми. В сучасних умовах слід відзначити широке використання інформаційно-вимірювальних технологій та інформаційно-технічних систем для виконання технологічних операцій у рослинництві.

Існуючі способи керування агробіологічним станом грунтового середовища та відбором проб грунту за наявними методиками не враховують варіабельності їх параметрів по площі сільськогосподарських угідь. Для реалізації технології диференційованого внесення технологічного матеріалу здебільшого використовується спрощений спосіб рівномірного розбиття поверхні поля на рівні квадрати (переважно площею 5-15 га) для подальшої діагностики та керування полем із використанням такої диференціації. За цією методикою до умовно рівного квадрата на полі можуть потрапляти ділянки 3 принципово різними параметрами, середнє значення яких не відображатиме реальних параметрів даної ділянки. Спосіб рівномірного розбиття на рівні квадрати поверхні поля не враховує специфіки поля та зон неоднорідності, як наслідок - низька достовірність даних, отриманих із використанням такого методу, а відповідно і можливість використання таких даних для якісного керування технологічними процесами 3 використанням технології диференційованого внесення технологічного матеріалу. Тому такий спосіб реалізації ди- ференційованого внесення технологічного матеріалу буде неефективним.

Один із головних підходів при застосуванні сучасних технологій землеробства оптимізувати урожайність і забезпечити екологічну якість сільськогосподарської продукції з урахуванням варіабельності зон управління сільськогосподарським полем (рис. 1).

Знання певної структури варіабельності грунтового покриву дозволяє прийняти ефективні рішення для управління агробіологічним потенціалом сільськогосподарських угідь [1].

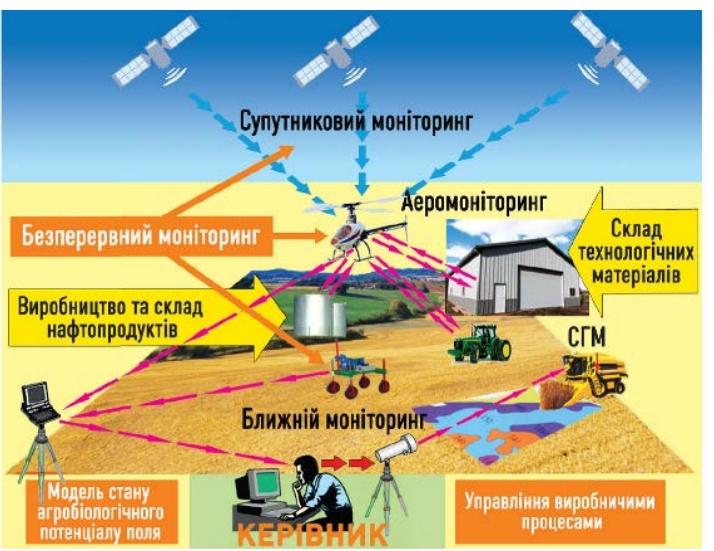

Рис. 1. Схема сучасного управління агробіологічним потенціалом агропідприємства

Таким чином, схема сучасного управління агробіологічним потенціалом сільсько- 
господарського агропідприємства (рис. 1) передбачає наявність загальних елементів: склад технологічних матеріалів, виробництво та склад нафтопродуктів, а також новітніх елементів сільськогосподарських підприємств для ефективного функціонування сільськогосподарського виробництва шляхом підвищення якості виконання технологічних операцій.

Важливим елементом цих технологій $\epsilon$ безперервний моніторинг стану сільськогосподарських угідь за трьома напрямами: супутниковий моніторинг (реалізація за допомогою супутників), аеоромоніторинг (з використанням літальних апаратів) та ближній моніторинг (за допомогою рухомих транспортних засобів). Така організація дає можливість сформувати модель стану агробіологічного потенціалу поля та прийняти керівнику (інженеру, агроному, начальнику відділу, голові господарства, начальнику відділу при міністерстві) ефективні рішення для управління агробіологічним потенціалом поля. Причому, керівник може проводити аналіз рішень дистанційно, незалежно від власного місця розміщення, 3 використанням мобільних обчислювальних засобів. Отримання достовірних даних можливе лише 3 використанням новітніх систем і науково обгрунтованих підходів до управління агробіологічним потенціалом поля.

Точне землеробство передбачає виконання $[1,2,3,7]$ кожної технологічної операції згідно $з$ відповідною картограмою, яка розробляється попередньо на основі різнопланової інформації. Загальну схему реалізації точного землеробства наведено на рис. 1.

Закономірним за сучасних умов розвитку техніки та ринкових відносин, що характеризуються розвитком інформаційних технологій і неухильним зростанням цін на енергоносії, є використання нових технологій для моніторингу, застосування яких дає можливість одержувати значний економічний ефект завдяки оптимальному використанню виробничих засобів і технологічних процесів. Невід'ємною складовою сучасного сільського господарства $\epsilon$ моніторинг агробіологічного та фітосанітарного стану сільськогосподарських угідь перед сівбою, протягом вегетації та при збиранні врожаю (рис. 2).

Завданням сучасного землеробства $\epsilon$ забезпечення належної ефективності сільськогосподарського виробництва шляхом інте- грації сучасних передових механікоконструктивних та інформаційно-технічних систем для прийняття ефективного оперативного управлінського рішення.

Неоднорідність вважають фактором, відповідальним за біорізноманіття, тому що завдяки їй формується екологічна складова i забезпечується багатогранність організмів грунту [2].

За межами типової системи інформаційного забезпечення процесів планування залишаються задачі, пов'язані з вибором оптимальних рішень, оцінкою альтернативних варіантів розвитку і т. ін.

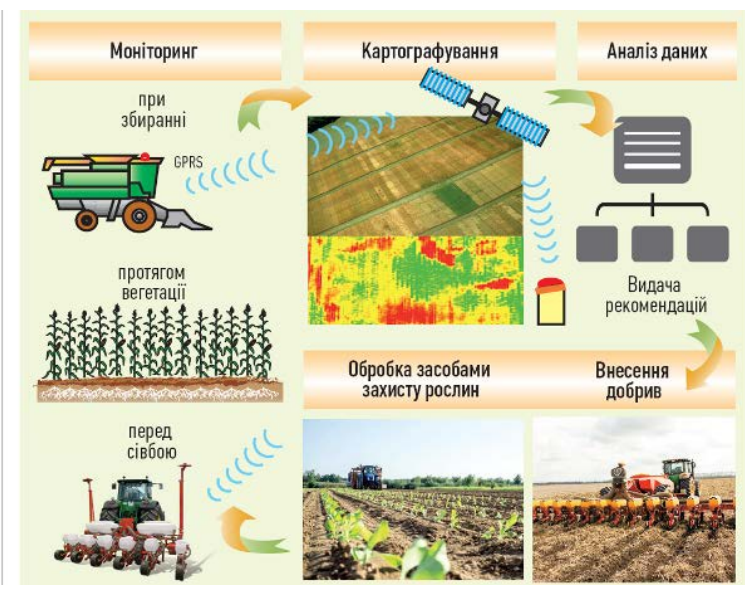

Рис. 2. Схема інформатизації сучасних технологій землеробства

У більшості сільськогосподарських підприємств, що використовують для автоматизації функцій планування системи операційного управління (розроблені на основі як типових, так і індивідуальних проектів), не можуть уникнути головного недоліку цього типу інформаційних систем: зміщення акцентів у бік поточного планування [4].

Очевидно, що за таких умов виникає необхідність у принципово нових підходах до ведення агропромислового виробництва, що полягає у забезпеченні належної якості виконання технологічних операцій. Якість виконання технологічних операцій $\epsilon$ інтегральним показником ефективності виробництва сільськогосподарської продукції в межах агробіологічного поля. Необхідна якість виконання основних технологічних процесів у рослинництві забезпечується за рахунок інтегрованих інформаційно-технічних систем оперативного моніторингу агробіологічного стану сільськогосподарських угідь [13-15]. 
На реальних характерних ділянках поля проводять необхідні експертні, агрохімічні, агрофізичні, біологічні та інші дослідження. Відомо, що виробництво та використання мінеральних добрив потребує значних затрат енергії. Наприклад, в країнах Східної Свропи вони становлять до $60 \%$ від загальних енерговитрат рослинництва [5]. Разом 3 тим, результати останніх агрохімічних обстежень грунтів показали, що достатню забезпеченість рухомими формами мають $2 / 3$, а обмінним калієм - 48 \% земель України [4]. Причому навіть у межах одного поля бувають грунти 3 різним ступенем забезпеченості засвоюваними поживними речовинами, які мають різну необхідність в обробці засобами хімічного захисту рослин.

На основі даних досліджень конкретного поля, а також даних «історії» цього поля, урожаю відповідної культури, що планується, метрологічних прогнозів, матеріальнотехнічного забезпечення господарства та інших факторів розробляються картограми рекомендованого обробітку характерних ділянок поля. Сучасне сільськогосподарське виробництво передбачає широке використання автоматизованих систем для моніторингу стану сільськогосподарських угідь - інформаційно-технічних систем локального оперативного моніторингу агробіологічного стану сільськогосподарських угідь.

Метою цього дослідження $є$ розробка методики виділення зон варіабельності агробіологічного стану сільськогосподарських угідь як основи ефективного використання сучасних інформаційно-технічних систем в агропромисловому виробництві.

Виклад основного змісту дослідження. Технології точного землеробства $\epsilon$ ефективним інструментом сільськогосподарського виробництва. На цьому етапі провідні лідеривиробники сільськогосподарських машин та знарядь націлені на їх адаптацію під реалізацію технологій точного землеробства. Причому, інструменти цих технологій закладені в базову комплектацію, що створює передумови для їх широкого впровадження у сучасних агропідприємствах. Проте, незважаючи на таку адаптацію та передумови для їх використання, частка їх використання у сучасних агропідприємствах досить низька.

На активність просторового перерозподілу елементів живлення в грунті впливають норма i форма внесених добрив, характер руху гравітаційної та капілярної вологи в грунті, вологість і температура грунту, його фізико-хімічні та біологічні властивості, а також спосіб внесення мінеральних добрив. Інформації щодо міграції елементів живлення за локального внесення мінеральних добрив у наукових джерелах майже немає.

Для досягнення оптимального забезпечення рослин елементами живлення необхідно забезпечити їх ефективне застосування шляхом використання оперативних даних про варіабельність агробіологічного стану грунтового середовища. В сучасних умовах господарювання найбільш ефективним способом застосування мінеральних добрив $€$ їх диференційоване локально-дозоване внесення. Дослідженнями, проведеними в різних грунтово-кліматичних зонах, встановлено, що кількісне і якісне оцінювання вмісту елементів живлення в грунті дає можливість точніше встановлювати оптимальні норми добрив та скорегувати дози і строки їхнього внесення.

Методика визначення зон варіабельності агробіологічного стану сільськогосподарських угідь призначена для використання у галузі сільського господарства та може бути використана в сучасних технологіях сільськогосподарського виробництва, технологіях точного землеробства, безпосередньо у рослинництві, загальному землеробстві і призначена для підвищення достовірності визначення агрохімічного стану грунтового середовища при оперативному агрохімічному обстеженні грунтів шляхом моніторингу агробіологічного стану грунтового середовища сільськогосподарських угідь, зокрема відбору проб грунту, оперативного визначення потенційної родючості грунтів для застосування технологій диференційованого локальнодозованого внесення технологічного матеріалу (добрив, насіння тощо), а також може бути застосована при виконанні агрохімічного обстеження грунтів власниками земель та землекористувачами.

У зв'язку з цим виникає необхідність у розробці методики визначення величини зон варіабельності агробіологічних параметрів сільськогосподарських угідь для забезпечення належної якості виконання технологічних операцій у рослинництві. Це дає можливість підвищити достовірність отриманих даних, а відповідно - i ефективність впровадження сучасних технологій сільськогосподарського виробництва. 
Виділення таких зон можливе з урахуванням величини варіабельності цих показників за трьома рівнями:

1. Дані дистанційного моніторингу агробіологічних параметрів сільськогосподарських угідь на основі даних супутникового моніторингу або з використанням дронів $X_{1}$.

2. Дані моніторингу урожайності, а відповідно - і рельєфу поля $X_{2}$.

3. Дані, отримані з використанням пристрою моніторингу електропровідних характеристик грунтового середовища, $X_{3}$.

Кожен 3 наборів цих даних може бути використаний окремо - $X_{1}, X_{2}, X_{3}$., або у комплексі 3 коефіцієнтами вагомості впливу на кінцевий коефіцієнт зон варіабельності $X_{3}$ :

$$
X_{3}=k_{1} \cdot X_{1}+k_{2} \cdot X_{2}+k_{3} \cdot X_{3} \text {, }
$$

де $k_{1}, k_{2}, k_{3}$ - коефіцієнти вагомості кожного показника при визначенні зон варіабельності.

Для виділення таких зон, перш за все, необхідно правильно визначити рівні варіювання таких даних (рис. 3).

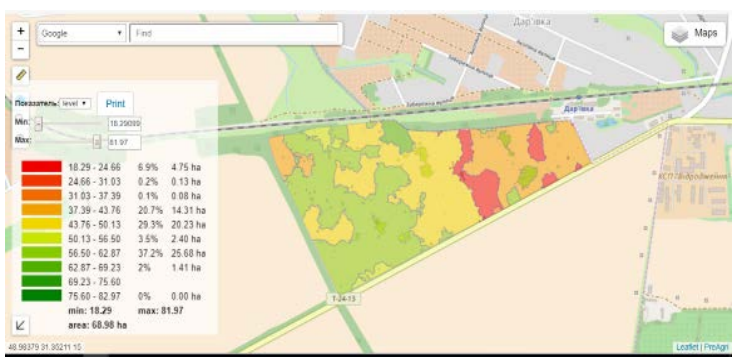

Рис. 3. Виділення зон варіабельності агробіологічного поля, отриманих з використанням показника електропровідності на основі комплексних показників

Залежно від величини параметрів варіабельності нижнього та верхнього показника стану грунтового середовища (урожайність, рельєф, електропровідність тощо) сільськогосподарських угідь та строкатості їх агробіологічних параметрів формується кількість рівнів варіабельності 3 мінімальним $Q_{\min }$ та максимальним $Q_{\max }$ значенням. Залежно від величини $\Delta=Q_{\max }-Q_{\min }$ визначають кількість рівнів варіювання $k$. Таким чином, величина кожного рівня $N$ варіювання визначається $\Delta_{N}=\frac{\Delta}{k}=\frac{Q_{\max }-Q_{\min }}{k}$.

Для виділення зон неоднорідностей необхідно виділяти зони неоднорідності на ос- нові даних (рис. 4). Таким масивом даних можуть бути:

- дані дистанційного моніторингу;

- дані урожайності агробіологічного стану сільськогосподарських угідь;

- дані електропровідних властивостей грунтового середовища.

Для цього спочатку отримані дані довільно з рівними інтервалами потрібно розбити на рівні частини. Рекомендовано п'ять рівнів.

Дані дистанційного моніторингу дають можливість виділити зони неоднорідності на основі аналізу даних з таких полів протягом декількох років (як правило, достовірні дані можна отримати на основі даних, отриманих протягом 3-5 років). Проте з такими даними важко працювати у вегетаційний період, оскільки їх неможливо інтерпретувати саме у цей період. Методика дозволяє виявити зони перекриття рослинами поверхні поля. У випадку неперекриття можна у вегетаційний період діагностувати неправильне виконання технологічних операцій або пошкодження посівів (наприклад, замокання чи вилягання). Проте при правильному пророщуванні сільськогосподарських культур, як правило, у вегетаційний період діагностувати ефективність сільськогосподарських угідь неможливо внаслідок їх повного покриття рослинами. Ефективна діагностика такими методиками можлива лише у період воскової стиглості, коли вже фактично неможливо виправити стан посівів та вплинути на кінцеву врожайність. Як правило, такі технології не дають ефективного результату у період червнявересня, i, відповідно, ефективність таких технологій дуже низька.

Дані урожайності $\epsilon$ ефективним інструментом моніторингу зон варіабельності неоднорідності. Проте після формування урожайності відбувається винесення поживних речовин 3 грунту, і на основі даних урожайності важко діагностувати реальний агробіологічний стан грунтового середовища. Дані потенційної урожайності показують реальний потенціал агробіологічних зон сільськогосподарських угідь, проте важко оцінити, внаслідок чого була сформована така врожайність: чи внаслідок потенціалу поля, чи внаслідок внесення поживних речовин, та який реальний їх залишок у грунті. Важко також оцінити, $з$ яким потенціалом залишилися зони агробіологічного поля. 
В ідеалі для виділення зон варіабельності потрібно мати три шари таких даних та оцінити ці зони на основі коефіцієнтів впливу на кінцеву зону.

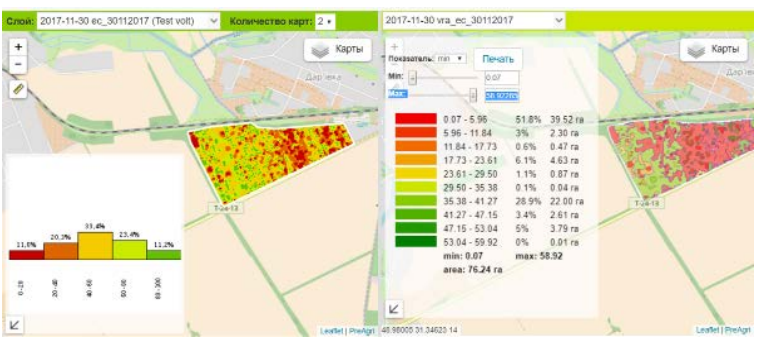

Рис. 4. Дані параметрів електропровідних харатеристик та виділені на їх основі зони варіабельності

Кожен із цих класів має свої переваги та недоліки. Найбільш об'єктивним і доступним 3 точки зору реалізації є моніторинг електропровідних властивостей стану грунтового середовища.

Зони варіабельності можуть коливатися від 0,01 га (менше економічно недоцільно) до десятків гектарів (20-50 га). Середнє значення таких зон варіабельності для природнокліматичних зон України коливається в межах 2-20 га.

Після формування таких зон варіабельності можемо сформувати зони неоднорідності та відповідно сформувати зони, переписані для відбору зразків грунтових проб. Як наслідок ми маємо чіткі дані по поверхні поля $з$ урахуванням таких зон, а відповідно - i високу достовірність отриманих даних, що надзвичайно важливо при формуванні зон варіабельності. Такі дані будуть актуальні при роботі з рівнями варіювання, які, до речі, не регламентовані нормативними документами та стандартами.

Далі маємо візуально оцінити закон, за яким такі дані можемо апроксимувати.

При реалізації технологій точного землеробства важливим елементом є моніторинг агробіологічного стану сільськогосподарських угідь, що є основою для прийняття рішення щодо стратегії керування.

Для виділення таких зон потрібно, як правило, враховувати три рівні інформації. Взагалі такі зони можна виділити на основі будь-якої інформації про поле 3 геоприв'язкою.

Висновки. Запропонована методика дає можливість виділити зони варіабельності агробіологічного стану сільськогосподарських угідь, що підвищує якість їх моніторингу при зменшенні трудомісткості та є основою ефективного використання сучасних інформаційно-технічних систем в агропромисловому виробництві. Проте при реалізації технологій точного землеробства перелік питань пов' язаний, перш за все, $з$ питаннями ефективного оперативного моніторингу на всіх стадіях вирощування сільськогосподарських рослин: перед сівбою, протягом вегетації та при збиранні врожаю.

Саме ці системи дозволяють ефективне використання сучасних інформаційнотехнічних систем у виробництві продукції рослинництва, зокрема шляхом використання диференційованого внесення технологічного матеріалу (насіння, добрив тощо) за допомогою інтелектуальних засобів. Техніка цього класу - це обладнання, яке дає змогу закривати практично увесь перелік технологічних операцій, пов'язаних із реалізацією технологій точного землеробства, на основі даних оперативного моніторингу стану сільськогосподарських угідь.

\section{Список літератури}

1. Ландау Л. Д., Лифшиц Е. М. Электродинамика сплошных сред. Москва: Наука, 1982. $624 \mathrm{c}$.

2. Вайнштейн Л. А. Электромагнитные волны. Москва: Радио и связь, 1988. 440 с.

3. Пархоменко Э. И. Геоэлектрические свойства минералов и горных пород при высоких давлениях и температурах. Москва: Наука, 1989. 198 с.

4. Басниев К. С., Кочина И. Н., Максимов В. М. Подземная гидромеханика. Москва: Недра, 1993. 416 с.

5. Александров П. Н. Эффективные электромагнитные параметры капиллярной системы электропроводности горной породы. Физика Земли. 2000. № 2. С. 87-94.

6. Федоров Ф. И. Теория гиротропии. Минск: Наука и техника, 1976. 456 с.

7. Третяков С. А. Электродинамика сплошных сред: киральные, биизотропные и некоторые бианизотропные материалы. Радиотехника и элетроника. 1994. Т. 39. Вып. 10. C. 1457-1470.

8. Chen C. L. IEEE Transatious. 1966. V. AP 14. №. 3. P. 283.

9. Chad Hertz A., Hibbard John D. A preliminary assessment of the economics of variable rate technology for applying phosphorus and potassium in corn production. Farm Economics. 
Iss. 14. Department of Agricultural Economics, University of Illinois, Champaign-Urbana. 1993. P. 218-231.

10.Медведев В.В.Неоднородность почв и точное земледелие. Ч. І. Введение в проблему. Харьков, 2007. 296 с.

11.Иванов Ю. П., Синяков А. Н., Филатов И. В. Комплексирование информационноизмерительных устройств ЛА. Ленинград: Машиностроение. Ленингр. отд., 1984. 207 с.

12.Вадюнина А. Ф. К оценке электропроводности как метода определения влажности почв. Почвоведение. 1937. № 3. С. 391-404.

13.Wilcox G. G. Determination of electrical conductivity of soil solutions. Soil Science. 1947. V. 63. P. 107.

14.Ewart G. Y., Baver L. D. Salinity effects on soil moisture electrical resistance relationships. Soil Sci. Soc. Amer. J. 1950. V. 15. P. 56-63.

15.Воробьев Н. И. К вопросу кондуктометрического определения засоленности почв и грунтов. Почвоведение. 1955. № 4. С. 103.

16. Rhoades J. D., Schifgaarde J. Van. An electrical conductivity probe for determining soil salinity. Soil Sci. Soc. Amer. J. 1976. № 5. P. 647-651.

17.Копикова Л. П. Опыт применения методов электропроводности для составления детальных почвенно-мелиоративных карт. Бюллетень ВИУА. 1979. № 43. С. 21-23.

18.ГОСТ 26423-85. Почвы. Методы определения удельной электрической проводимости, $\mathrm{pH}$ и плотного остатка водной вытяжки. 7 с.

19.Pansu M., Gautheyrou J. Handbook of soil analysis. Mineralogical, organic and inorganic methods. Springer-Verlag Berlin Heidelberg. 2006. P. 993.

20.URL: http://agrotehnology.com/tochnoezemledelie/ideologi/o-chem-rasskazyvaetudelnaya-elektroprovodnost-pochvy.

21.Гуков Я. С., Линник Н. К., Мироненко В. Г. Автоматизированная система локальнодозированного внесения удобрений, мелиорантов и средств защиты растений. Tруды 2й МНПК по проблемам дифференциального применения удобрений в системе координатного земледелия. Рязань, 2001. С. 48-50.

22.Броварець О. Від безплужного до глобального розумного землеробства. Техніка $i$ mехнології АПК. 2016. № 10 (85). С. 28-30.

23. Адамчук В. В., Мойсеєнко В. К., К Кравчук В. І., Войтюк Д. Г. Техніка для землеробства майбутнього. Механізація та електрифікачія сільського господарства. Вип. 86. Глеваха: ННЦ «ІМЕСГ», 2002. С. 20-32.
24.Сучасні тенденції розвитку конструкцій сільськогосподарської техніки / за ред. В. I. Кравчука, М. І. Грицишина, С. М. Коваля. Київ: Аграрна наука, 2004. 398 с.

25.Ормаджи К. С. Контроль качества полевых работ. Москва: Росагропромиздат, 1991. $191 \mathrm{c}$.

26. Масло І. П., Мироненко В. Г. Автоматизована система локально-дозованого внесення добрив і хімічних засобів захисту рослин. УААН: Розробки - виробництву. Київ: Аграрна наука, 1999. С. 348-349.

\section{References}

1. Landau, L. D., Lifshits, E. M. (1982) Electrodynamics of continuums. Moscow: Nauka, 624 p. [in Russian].

2. Vaynshteyn, L. A. (1988) Electromagnetic waves. Moscow: Radio i svyaz, 440 p. [in Russian].

3. Parhomenko, E. I. (1989) Geoelectric properties of minerals and rocks at high pressures and temperatures. Moscow: Nauka, 198 p. [in Russian].

4. Basniev, K. S., Kochina, I. N., Maksimov, V. M. (1993) Underground hydromechanics. Moscow: Nedra, 416 p. [in Russian].

5. Aleksandrov, P. N. (2000) Effective electromagnetic parameters of capillary system of rocks electrical conductivity. Fizika Zemli, No. 2, pp. 87-94 [in Russian].

6. Fedorov, F. I. (1976) The theory of gyrotropy. Minsk: Nauka i tehnika, 456 p. [in Russian].

7. Tretyakov, S. A. (1994) Electrodynamics of continuums: chiral, double-isotropic and some double-anisotropic materials. Radiotehnika $i$ eletronika, vol. 39, iss. 10, pp. 1457-1470 [in Russian].

8. Chen, C. L. (1966) IEEE Transatious, vol. AP - 14, No. 3, p. 283.

9. Chad, Hertz A., Hibbard, John D. (1993) A preliminary assessment of the economics of variable rate technology for applying phosphorus and potassium in corn production. Farm Economics, iss. 14. Department of Agricultural Economics, University of Illinois, ChampaignUrbana, pp. 218-231.

10.Medvedev, V. V. (2007) Soil heterogeneity and precision farming. Part I. Introduction to the problem. Kharkov, 296 p. [in Russian].

11.Ivanov, Yu. P., Sinyakov, A. N., Filatov, I. V. (1984) Interconnecting of information and measuring LA devices. Leningrad: Mashinostroenie, Leningr. otd., 207 p. [in Russian].

12. Vadyunina, A. F. (1937) To the assessment of electrical conductivity as a method for deter- 
mining soil moisture. Pochvovedenie, No. 3, pp. 391-404 [in Russian].

13.Wilcox, G. G. (1947) Determination of electrical conductivity of soil solutions. Soil Science, vol. 63, p. 107.

14. Ewart, G. Y., Baver, L. D. (1950) Salinity effects on soil moisture electrical resistance relationships. Soil Sci. Soc. Amer. J., vol. 15, pp. 56-63.

15. Vorobyev, N. I. (1955) To the question of conductometric determination of soil and ground salinity. Pochvovedenie, No. 4, p. 103 [in Russian].

16.Rhoades, J. D., Schifgaarde, J. Van. (1976) An electrical conductivity probe for determining soil salinity. Soil Sci. Soc. Amer. J., No. 5, pp. 647-651.

17.Kopikova, L. P. (1979) Experience of using electrical conductivity methods for compiling detailed soil-reclamation maps. Byulleten VIUA, No. 43, pp. 21-23 [in Russian].

18. GOST 26423-85. Soils. Methods for determining specific electrical conductivity, $\mathrm{pH}$ and dense residue of aqueous extract, 7 p. [in Russian].

19.Pansu, M., Gautheyrou, J. (2006) Handbook of soil analysis. Mineralogical, organic and inorganic methods. Springer-Verlag Berlin Heidelberg, p. 993.

20.URL: http://agrotehnology.com/tochnoezemledelie/ideologi/o-chem-rasskazyvaetudelnaya-elektroprovodnost-pochvy
21.Gukov, Ya. S., Linnik, N. K., Mironenko, V. G. (2001) Automated system of locally dosed application of fertilizers, meliorants and plant protection products. Trudyi 2-y MNPK po problemam differentsialnogo primeneniya udobreniy $v$ sisteme koordinatnogo zemledeliya. Ryazan, pp. 48-50 [in Russian].

22.Brovarets, O. (2016) From plowless to the global rational agriculture. Tehnika $i$ tehnologiyi APK, No. 10 (85), pp. 28-30 [in Ukrainian].

23.Adamchuk, V. V., Moyseenko, V. K., Kravchuk, V. I., Voytyuk, D. G. (2002) Engineering for agriculture of the future. Mehanizatsiya ta elektrifikatsiya silskogo gospodarstva. Glevaha: NNTs «IMESG», iss. 86, pp. 20-32 [in Ukrainian].

24.Kravchuk, V. I., Gritsishin, M. I., Koval, S. M. (eds.) (2004) Modern trends in the development of agricultural machinery constructions. Kyiv: Agrarna nauka, 398 p. [in Ukrainian].

25.Ormadzhi, K. S. (1991) Quality control of field works. Moscow: Rosagropromizdat, 191 p. [in Russian].

26. Maslo, I. P., Mironenko, V. G. (1999) Automated system of locally-dosed fertilizers and chemical plant protection products. UAAN: Rozrobky - vyrobnytstvu. Kyiv: Agrarna nauka, pp. 348-349 [in Ukrainian].

O. O. Brovarets, Ph.D., associated professor

e-mail: brovaretsnau@ukr.net

Kyiv Cooperative Institute of Business and Law

Lomonosov str., 18, Kyiv, 03041, Ukraine

\section{THE USE OF MODERN INFORMATION AND TECHNICAL SYSTEMS IN AGRICULTURAL PRODUCTION}

The article is devoted to optimization of productivity and provision of ecological quality of agricultural products with the help of modern information and technical systems, taking into account the variability of zones of management by agricultural field. It is proposed to represent the heterogeneity of the soil as a hierarchical subordination of phenomena. At the same time, the issue of measuring heterogeneity is proposed to be solved by quantitative comparison of measuring objects using the appropriate criteria. Under these conditions, there is a need to find the most effective way for operational monitoring of agrobiological state of agricultural land, which opens new prospects for organic farming using intelligent agricultural machines. value.

Keywords: information and technical system, operational monitoring, soil, samples, variability,

Стаття надійшла до редакиії 03.09.2018.

Рецензенти: В. С. Антонюк, д.т.н., професор,

В. Я. Гальченко, д.т.н., професор. 